\title{
Willem Christiaan van Manen: \\ A Dutch Radical New Testament scholar
}

\author{
E Verhoef \\ Hollandsche Rading \\ The Netherlands
}

\begin{abstract}
$W C$ van Manen is the most fascinating representative of the 'Dutch Radicals'. In his opus magnum (1890-1895), Paulus, he argued that we do not have any authentic Pauline epistles. Earlier, in 1865, he had defended the thesis that Paul was the author of 1 Thessalonians. After his appointment as a professor in Leiden we can see his growing doubt about the authenticity of even the four main epistles: Romans, 1 and 2 Corinthians and Galatians. In 1889 Van Manen said for the first time that, in his opinion, we do not have any authentic Pauline epistles. The importance of Van Manen is that he compels us to account for our opinions regarding the authorship of the thirteen 'Pauline' epistles.
\end{abstract}

\section{INTRODUCTION}

Biblical exegesis in the last century underwent very interesting developments. Critical study of the New Testament became more and more important. Everyone knows the name of the famous German scholar F C Baur. Regarding the Pauline epistles Baur concluded that we do not have more than four authentic Pauline epistles: Romans, 1-2 Corinthians and Galatians. Baur can be considered the exegete who marks the beginning of a new era.

In the Netherlands there was a similar though not equal development. In the eighties and the nineties of the last century the so-called 'Dutch Radical School' arose. A D Loman used the word 'radical' in 1887 in an article published in Theologisch Tijdschrift. In his opinion scholars should be 'radical' in their research of New Testament writings.

Probably the most fascinating representative of this school is W C van Manen. He produced more than three hundred publications, most of them dealing with topics relating to the Pauline epistles (see Verhoef 1984:73-90). 1 His views underwent a big development. First he defended the authenticity of 1 Thessalonians, but later he argued that we do not have any authentic Pauline epistle at all. First of all I would like to describe Van Manen's life and views, after which I will give an evaluation of these views. ${ }^{2}$ 
Van Manen was born in 1842 in Noordeloos, a small village near Utrecht. His father, Hugo van Manen, was a minister in the Dutch Reformed Church there. After his secondary education Van Manen studied theology at the University of Utrecht. The professors there were rather orthodox. More than once Van Manen protested against what he felt to be a straitjacket (see Verhoef 1984:13-15). Professors J J Van Oosterzee and J I Doedes were especially criticised. In his book Een woord over Utrechtse Theologie - he was still a student - Van Manen (1864:17) denounced these professors and their lectures (see Verhoef 1984:14). It seems that they cast doubt on the belief of the students with 'modern' opinions.

W C van Manen was not the first of his family to have problems with the orthodox supremacy in many churches and in some universities. We do not have much information about his father, but his grandfather - also called Willem Christiaan van Manen - got into difficulties with his church in Amsterdam already in 1827. A woman of his congregation wrote to him that she often visited the Mennonite church because it was in that church that she heard the important truths of salvation. For her, the service in her own church raised the question: is this perhaps a Remonstrant church (see Verhoef 1984:9).

In 1865 Van Manen wrote a dissertation on the authenticity of 1 Thessalonians. As was said above, at that time he defended the authenticity of this letter. In the same year A B van der Vies (see Verhoef 1998:437-438) argued that both epistles, 1 Thessalonians and 2 Thessalonians, were inauthentic (see Van Manen's [1866:97-166] reaction to Van der Vies). The different results of their research were to a great extent predictable because of their different starting points. Van Manen (1865:43-46, 138-139) argued in the following way: ' 1 Thessalonians is introduced to us as an epistle written by Paul. We should investigate if matters are treated or words are used in this epistle that speak against the Pauline origin' (cf. also Van Manen 1866:102). Van der Vies reasoned very differently: 'Either the prescript of the epistle is conclusive or the prescript does not tell us anything about the epistle's authorship' (in Dutch: 'Dat opschrift bewijst ALLES of NIETS.') According to Van der Vies the prescript does not say anything, so the research is totally open.

In the next two decades Van Manen was minister in the Reformed Church in, successively, Abbenbroek, Winkel and Zierikzee. From the minutes of the church council meetings we know that Van Manen was not afraid to air his opinions. He was as pugnacious as he was in his student days. Already a few months after his appointment in Abbenbroek he told his congregation at Easter that he did not believe in the physical resurrection of Christ. Previously he had agreed with two colleagues that they would bring the same message. The next day each of them would preach in their colleague's 
church and in this way the congregation heard the same opinion a second time, now from another minister (see Verhoef 1984:16).

In this period he found time to study, and published many articles. Van Manen had been a professor in Groningen for a few months. In 1885 he was appointed professor in Leiden. He stayed there until his death in 1905 . From 1885 he published more and more on his field of expertise: the Pauline epistles. A big problem to him was how to understand the development of Christianity in the first century, as so different movements were discernible in the Pauline epistles. In these publications Van Manen opposed himself to opinions such as those uttered by A D Loman, A Pierson and S A Naber, who argued that we do not have any authentic Pauline epistles. Van Manen's (1886) study, entitled Het Nieuwe Testament sedert 18593 discussed New Testament research in the Netherlands. This book is interesting in that we can discover the beginnings of a change in his reasoning. It seems to me that here Van Manen is less fiercely opposed to Loman, for example, than before. Two or three years after the publication of this book we see what is, according to Van den Bergh Eysinga (1912:81), called Van Manen's 'conversion'. This change in Van Manen's life can be reconstructed from his articles.

In 1887 Van Manen reviewed Die synoptischen Evangelien nach der Form ihres Inhaltes, written by C Holsten (see Van Manen 1887:326-343). Holsten stated that a succession of Petrinism, Paulinism, Judaism and Catholicism was the most plausible solution for an outline of the beginnings of Christianity. Van Manen (1887:343) argued in his review that this outline would be very attractive indeed if Paul might be dissociated from the four main epistles.

In the same year Van Manen reviewed a study written by W Seufert, Der Ursprung und die Bedeutung des Apostolates in der Christlichen Kirche der ersten zwei Jahrhunderte. This review was not published until 1889 (see Van Manen 1889a:205-274). Seufert argued in the same way as Holsten, though there are some differences. Again it is clear that slowly but surely Van Manen was being attracted to radical opinions such as Loman's. Van Manen argued that Seufert gave many arguments to strengthen the thesis proposed by Holsten, but in Van Manen's view this thesis could not be upheld because the main epistles were written in the middle of the first century. Van Manen (1889a:273) complained: 'it was a waste of time to argue in favour of Seufert's opinions as long as these epistles were dated in 52-63 and not 50 to 60 years later.'4 Van Manen (1889a:274) ended his review of the book by Seufert: 'if research should lead to the conclusion that Paul did not write these epistles, then we know the history of the development of the apostleship.' 
It is a book written by $R$ Steck that convinced Van Manen (1889b:322-339, 419438) that the authenticity of the Pauline epistles could not be upheld. In Steck's book, Der Galaterbrief nach seiner Echtheit untersucht nebst kritischen Bemerkungen zu den paulinischen Hauptbriefen, it was argued that the epistle to the Galatians, the epistles to the Corinthians and the epistle to the Romans had been written in the second century (see Verhoef 1996:429).5 Van Manen concluded that the arguments used by Steck were convincing. Perhaps more importantly, in this way Van Manen found the solution to the problem concerning the development of Christianity in the first and second centuries. For several years Van Manen had been obsessed with the question of socalled Paulinism. To him Paulinism had seemed to be a sudden phenomenon. Now it was clear that instead, Paulinism was 'the result of a long development' (see Van Manen 1889b:424)6. From now on, he stated, he would try to place the epistles in their historical context 7 .

So the 'conversion' of Van Manen was a fact. Later on in his magnum opus, Paulus (Van Manen 1890, 1891, 1896), especially in part II, Van Manen (1891:288296) wrote again about the development of Christianity. In agreement with Holsten, Van Manen (1891:289) spoke of a succession of Petrinism, Paulinism, Judaism and Catholicism. In his opinion the 'Pauline' writings could be understood as products of the last stage of this development. We find in them fragments and revisions of older texts and in these writings we can see the different groups which took part in the development of Christianity (see Van Manen 1891:210-230).

We see now that Van Manen started his research of the Pauline epistles with a study on 1 Thessalonians. In this study he concluded that 1 Thessalonians was an authentic epistle as he could not find anything that spoke against the Pauline authorship. Later on he argued the other way around: 'we have an idea of the development of the oldest Christianity and we have to look for the place and time where these epistles fit best. What is said in the prescripts of the epistles is not relevant anymore.'

After this sketch of Van Manen's life and views I would like to give an evaluation of his work. Most scholars, apart from exceptions like, for example, the German minister Hermann Detering (1992, 1995, 1996; of Verhoef 1995:22), do not accept anymore the arguments used by Van Manen in his later studies (see Verhoef 1996:430432). The succession of Petrinism, Paulinism, Judaism and Catholicism cannot be upheld. On the contrary, we know that in the very beginning of Christianity a surprising diversity could be found in the congregations. These different movements, whatever they may be called, existed next to one another, not necessarily after one another. Van Manen's outline of the history of the oldest Christianity made the conclusion inevitable that the 'Pauline' epistles were inauthentic. 
This is not the time or place to discuss the problem of the authenticity of the epistles extensively, but I would like to make some remarks on that point. As far as I know most authors do not say very much about the authenticity of the Pauline epistles. Very often their authenticity is taken for granted. In the case of the disputed letters, for example 2 Thessalonians, many authors constrain themselves to disproving the arguments used by defenders of the inauthenticity. But if the in-authenticity of any epistle is invalidated, its authenticity is not proved yet. And also for the undisputed Pauline epistles we have to render account of our points of view.

In my opinion the following reasoning can be defended. We have several epistles that start their preseript by mentioning Paul as their author or sender, sometimes beside others. So the name of the author or sender of the epistle to the Romans is Paul. After reading this epistle we have a perception of the vocabulary, the style and the theology of this author. Reading other epistles which purport to originate from Paul, we find a similar vocabulary and style and theology in 1 and 2 Corinthians, Galatians, Philippians, 1 Thessalonians and in Philemon. We may conclude then that these epistles have been written by this Paul as well. With the help of data from these letters, for example Galatians 2 and 2 Corinthians 1:19; 11:32-33; 1 Thessalonians 2:2 and so on, we can roughly reconstruct a chronology of the life of this man.

It is surprising that we can find a similar reasoning in Van Manen's dissertation. In my opinion this reasoning is a sound one. Van Manen's conversion was caused by his disbelief in a very fast development of Christianity in the first century. He saw a succession of the different trends in Christianity. in the course of about a hundred years, but in my opinion these trends could be found from the beginning simultaneously in the Christian congregations.

In this reasoning the name mentioned in the prescript offers an argument that is not conclusive in itself. The second epistle to the Thessalonians, for example, raises many problems regarding a possible Pauline authorship (see Verhoef 1998b:163-171; 1998c:2835). In this epistle we find striking differences with regard to eschatology in comparison with 1 Thessalonians. Therefore many scholars conclude that 2 Thessalonians is pseudepigraphic though Paul is mentioned in the prescript (Lietaert Peerbolte 1995:64-68; Richard 1995:19-29; Van Aarde 1996:253-265; Verhoef 1998c:3335).

The importance of Van Manen is, apart from his efforts for freedom of thought in the church, that he compelled us to account for our opinions regarding the authorship of the New Testament epistles. No authorship can be certain in advance; it has to be proved or at least to be made probable. 


\section{End Notes}

1 Beside books and articles concerning the New Testament, Van Manen wrote among others about uncertainties, spiritism, Roman Catholicism, church history, his journeys abroad.

2 I am indebted to Mrs Drs J W van Arenthals for correcting my English.

3 This book is a revision of several articles, published earlier in German, in Jahrbucher fur protestantische Theologie 9 (1883), 593-618; 10 (1884), 269-315, 551-626; 11 (1885), 86122, 454-496; 12 (1886), 418-455.

4 'Maar wat waag ik mij aan opvattingen en voorstellingen, die immers niet kunnen worden toegelaten, tenzij vooraf het bewijs mocht zijn geleverd, dat de Paulinische hoofdbrieven niet dagteekenen uit de jaren 52 (55)-63, maar minstens 50 a 60 jaar later zijn geschreven' (Van Manen 1889a:273; see also Verhoef 1984:48).

5 'Es leuchtet ein, dab die Beweggründe für Van Manen, sich zul den radikalen Standpunkten zu "bekehren" [...] eng mit der erwähnten Rekonstrultion der Geschichte des Urchristentums zusammenhängen' (Verhoef 1996:429).

6 'Nu doet zich het Paulinisme niet meer aan ons voor als cen uit den hemel gevallen verschijnsel [...] maar als de slotsom eener lange ontwikkeling' (Van Manen 1889b:424).

7 '[M]en tracht ze [...] in de geschiedenis van het oorspronkelijk Christendom daar te platsen, waar zij behoren' (Van Manen 1989b:424).

\section{Works consulted}

Detering, H 1992. Paulusbriefe ohne Paulus? Die Paulusbriefe in der hollandischen Radikalkritik. Frankfurt am Main: Peter Lang 1995. Der gefalschte Paulus. Düsseldorf: Patmos.

1996. The Dutch radical approach to the Pauline epistles. The Journal of Higher Criticism 3/2, 163-193.

Lietaert Peerbolte, L J 1995. The antecedents of Antichrist. Leiden.

Loman, A D 1887. Een engelsche anonymus over den oorsprong des christendoms. Theologisch Tijdschrift 21.

Richard, E J 1995. First and Second Thessalonians. Collegeville: The Liturgical Press.

Van Aarde, A G 1996. The Second Letter to the Thessalonians re-read as pseudepigraph. The Journal of Higher Criticism 3/2, 237-266.

Van den Bergh van Eysinga, G A 1912. Die hollandische radikale Kritik des Neuen Testaments. Jena: Diederichs. 
Van der Vies, A B 1865. De beide brieven aan de Thessalonicensen. Leiden: Van Doesburgh.

Van Manen, W C 1864. Een woord over Utrechtse Theologie. Utrecht: L E Bosch.

- 1865. Onderzoek naar de echtheid van Paulus' eersten brief aan de Thessalonicensen. Weesp: Brugman.

1866. De echtheid van Paulus' eersten brief aan de Thessalonicensen. Godgeleerde Bijdragen 40, 97-166.

1886. Het Nieuwe Testament sedert 1859. Groningen: J B Wolters.

1887. Boekbeoordelingen. Theologisch Tijdschrift 21, 326-343.

1889a. Twaalf apostelen. Bibliotheek van moderne theologie en letterkunde 9, 205-274.

1889b. De hoofdbrieven van Paulus. De Tijdspiegel 1, 322-339; 419-438.

1890. Paulus, 1. Leiden: Brill.

1891. Paulus, 2. Leiden: Brill.

1896. Paulus, 3. Leiden: Brill.

Verhoef, E 1984. W C van Manen: Een Hollandse radicale theoloog. Kampen: Kok. 1996. Die holländische Radikale Kritik, in Bieringer, R (ed), The Corinthian Correspondence, 427-432. Leuven: Peeters.

1998a. S v A B van der Vies. Biografisch Lexicon voor de geschiedenis van het nederlands protestantisme, IV, 437-438. Kampen: Kok.

1998b. The relation between 1 Thessalonians and 2 Thessalonians and the inauthenticity of 2 Thessalonians. HTS 53/1\&2, 163-171.

1998c. De brieven aan de Tessalonicenzen. Kampen: Kok.

1995. Geen brief van Paulus? Interpretatie 3/4. 